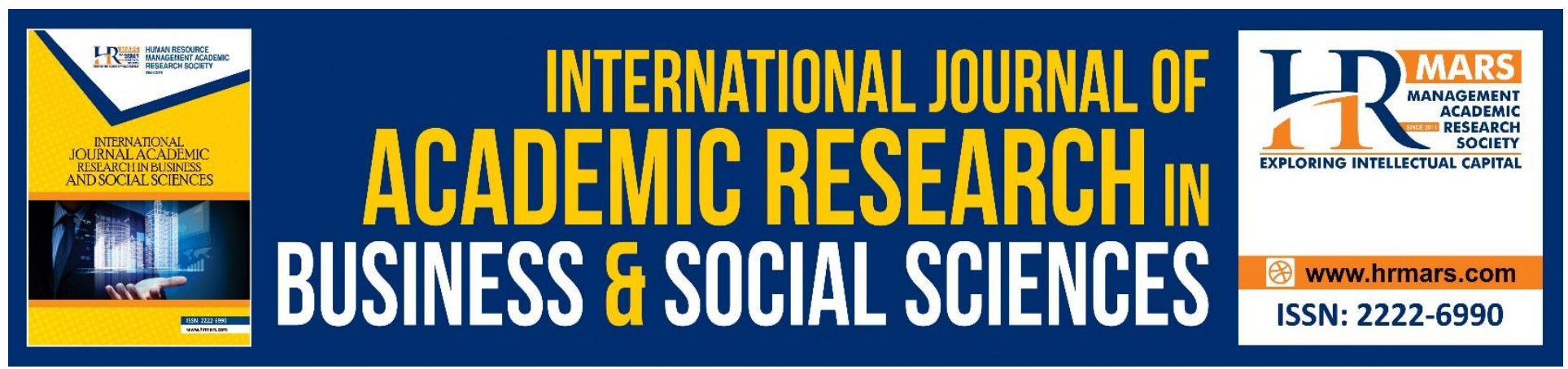

\title{
Competency of School Principals in Managing Change in Malaysian Secondary Schools: Teachers' Perspective
}

Tai Mei Kin, Omar Abdull Kareem, Arsalan Mujahid Ghouri

To Link this Article: http://dx.doi.org/10.6007/IJARBSS/v9-i6/5947 DOI: $10.6007 /$ IJARBSS/v9-i6/5947

Received: 15 April 2019, Revised: 22 May 2019, Accepted: 03 June 2019

Published Online: 27 June 2019

In-Text Citation: (Kin, Kareem, \& Ghouri, 2019)

To Cite this Article: Kin, T. M., Kareem, O. A., \& Ghouri, A. M. (2019). Competency of School Principals in Managing Change in Malaysian Secondary Schools: Teachers' Perspective. International Journal of Academic Research in Business and Social Sciences, 9(6), 285-304.

\section{Copyright: (c) 2019 The Author(s)}

Published by Human Resource Management Academic Research Society (www.hrmars.com)

This article is published under the Creative Commons Attribution (CC BY 4.0) license. Anyone may reproduce, distribute, translate and create derivative works of this article (for both commercial and non-commercial purposes), subject to full attribution to the original publication and authors. The full terms of this license may be seen

at: http://creativecommons.org/licences/by/4.0/legalcode

Vol. 9, No. 6, 2019, Pg. 285 - 304

Full Terms \& Conditions of access and use can be found at http://hrmars.com/index.php/pages/detail/publication-ethics 


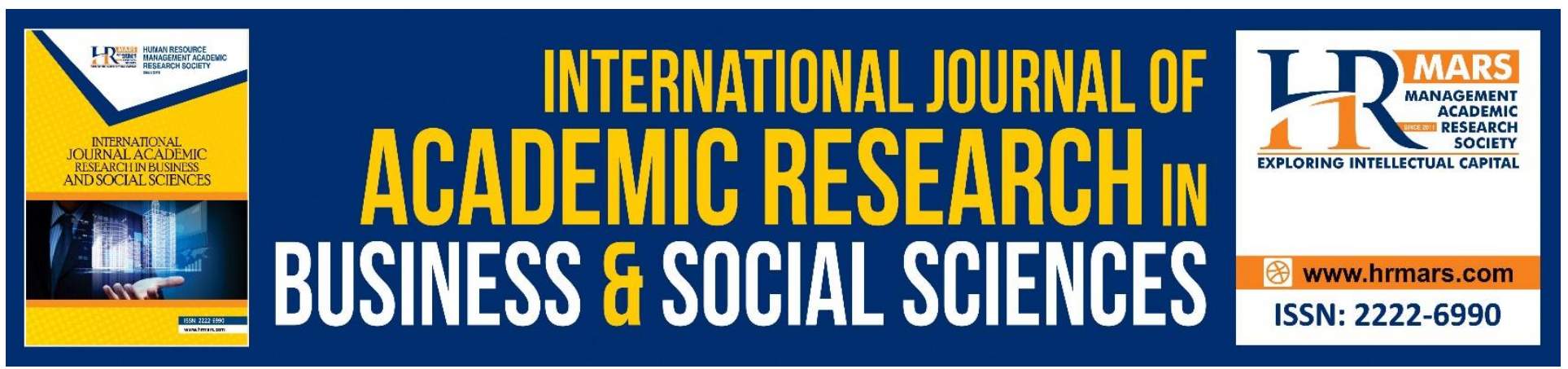

\title{
Competency of School Principals in Managing Change in Malaysian Secondary Schools: Teachers' Perspective
}

\author{
Tai Mei Kin, Omar Abdull Kareem, Arsalan Mujahid Ghouri \\ Faculty of Management and Economics, Sultan Idris Education University, 35900 Tanjong Malim, \\ Perak Darul Ridzuan, Malaysia \\ Email: taimeikin@fpe.upsi.edu.my
}

\begin{abstract}
The increasing demands for school reform continuously challenge the roles of school leaders as change agents in the process of school change. Today, school leadership is not task driven per se but emotionally compelling. The aim of the study was to identify the level of competency in managing change (CIMC) of school principals in Malaysian secondary schools. Analysis of the survey was performed based on the data of 901 teachers. The findings revealed that, i) school principals were rated as Quite Good in CIMC; ii) in terms of dimensions, school principals were reported Quite Good both in Technical and Non-technical Competency; iii) in terms of sub-dimensions of CIMC, the school principals were rated as Good in Goal Framing, Institutionalizing, Emotional Utilization and Emotional Regulation but Quite Good in Capacity Building, Defusing Resistance and Conflicts, Emotional Perceiving and Expressing as well as Emotional Understanding; and iv) among all the sub-dimensions of CIMC, the school principals obtained the highest mean score in Goal Framing and achieved the lowest mean score in Defusing Resistance and Conflicts. The study offers the Ministry of Education, local practitioners and relevant parties another dimension of enhancing and enlarging school principals' capacity for change.
\end{abstract}

Keywords: Change Leadership, Competency in Managing Change, School Reform, Technical Competency, Non-Technical Competency

\section{Introduction}

Education landscape is shifting rapidly due to the global dynamics and the advancement of technology. In line with this, many countries have embarked on educational reforms to improve student learning outcomes as education is at the heart of preparing present and future generations to thrive in the competitive world (Mohamed, Valcke \& De Wever, 2017). However, most of the reform efforts have fallen short of expectations (Balogun \& Hope-Hailey, 2004) or remained elusive 
(Harris, Jones \& Huffman, 2018; Olivier \& Huffman, 2016). One potential factor is the absence of leadership for change (Fullan, 2007; Tai \& Omar, 2018a). Indeed, research on education has found that effective change is difficult to be occurred in educational organizations unless the school leaders are able to initiate the change process competently (Oplatka, 2003; Tai \& Omar, 2018c).

Effective change leadership is the key in the educational system as it is the engine of change and school reform can only happen when guided by leadership (Patti, Senge, Madrazo \& Stern, 2015; Harris, 2004; Issah. 2018). School leaders are center to school effectiveness and improvement as school leadership impacts student learning (Fullan, 2010; Cotton, 2003; Leithwood, Louis, Anderson, \& Wahlstrom, 2004; Marzano, Waters, \& McNulty, 2005). Therefore, topics on school leadership have captured widespread attention and garnered enormous interest in educational research over the past decade. Successful school leaders of change not only being responsive to a rapidly changing external environment, importantly, they are able to put their competencies in place to drive and transform the organization effectively. Specifically, as change agents, school leaders are responsible for change strategy, implementation and monitoring and thus it is essential for them to equip with specific change leadership competency (Hyland, 2007).

As school change always challenges the most basic assumptions about the organization's status quo, the school principals are force to work within roles that involve multiple changing demands (Tai \& Omar, 2018b). Due to the complexities of the change initiatives coupled with the changing dynamics of human relations during the change process, it is not easy for school principals to settle different kinds of complex problems in the face of change with cognition alone as change is inherently emotional process (Pamer \& De Waal, 2011). According to Tai and Omar (2018a), school reform can only be realized and sustained continually if school principals are able to engage both intellectually and emotionally specifically in terms of continuous school improvement and effectiveness. In relation to this, researchers can no longer afford to investigate change leadership competency of school leaders based on technical competence alone.

Since the launching of the Malaysia Education Blueprint 2013-2025 in 2013, the education system in Malaysia is entering a period of intensive change. As school leadership impacts student achievements, to have an effective principal in each school is one of the important shifts outlined in the Blueprint to transform the education system successfully (Ministry of Education Malaysia, 2016). To this end, school principals need to be equipped with subsequent competencies to initiate the school change process effectively to meet the evolving and ever-changing demands of stakeholders. Against this background, it is particularly meaningful to examine the competency of the school principals in managing change in Malaysian secondary schools, both technical and non-technical competencies, in the midst of the implementation of the Blueprint as it can provide useful feedback that can inform and guide practices in school improvement and success.

\section{Leadership, Change and Competency}

Although the leadership literature is extremely rich but there is no any single leadership model that is universally accepted, nor any consensus upon the definition of "leadership". Nevertheless, there are some similarities in the manner how leadership is explained. Leadership is commonly refers as a process whereby an individual influences a group of individuals to achieve a common goal (Northouse, 2015). To this end, they need to set a direction and develop the necessary strategies to 
move in that direction. In other words, by creating and achieving a vision, leadership therefore is viewed as a process links with change.

Early in the year 1985, Bennis and Nanus (1985) emphasize that, 'Management is doing things right; leadership is doing the right things'. This matched with what Kotter (1990) highlights that "management is about coping with complexity; leadership, by contrast, is coping with change" (p. 86). Arguing the same point, Elliott (1992) points out that without change no leadership had occurred. Further, Kerfoot (1999) claims that leadership is the art and science of leading change effectively. In the same vein, Yukl (2002) stress that leading change is the basic role of a leader and other task is secondary. In summary, leadership is a dynamic process that the leader(s) and followers interact in a way that they can create and drive change and brings the organization to the next level and thus leadership links inexorably to the management of change.

As change is evidently a crucial facet of leadership and inducing change and engaging others to change are central to leadership, leaders require the wisdom to recognize the urgency for change and equally important the ability to manage change. As such, it is essential for leaders to possess specific change leadership competency to deal and cope with the dynamics within or outside the organization during the change. Leadership competencies are seen as the knowledge, skills, abilities, and attributes possess by the leaders so that they can perform their tasks and roles excellently (Tai \& Omar, 2018a). It is important to note that by conceptualizing leadership in terms of competency indicates that leadership can be learned and taught (Intagliata, Ulrich, \& Smallwood, 2000). Succinctly, by gaining and practising new knowledge, skills and ability individuals can become more effective leaders.

On the other hand, competencies can be divided into technical and non-technical (Rothwell, Hohne \& King, 2007). During a change process, technical competencies are specific to certain role to cope with the change whereas non-technical competencies such as emotional intelligence (EI) are core competencies that can be applied across the complete terrain of the process of change (Tai \& Omar, 2013). Leader with either technical or non-technical competencies is insufficient for effective change leadership (Omar \& Tai, 2018). Indeed, the increasing demands for accountability and organizational effectiveness constantly challenge both competencies to be complemented with each other that enable leaders to best lead change in the organization.

With the increasing demands for educational excellence schools are subject to frequent largescale reforms. Today, the role of the school leaders is challenging and complex specifically in the pathway to improve school effectiveness that links closely to student achievement. School is a dynamic and complex organization whereby school leadership is embedded in broader social relationships; it involves rational and cognitive activities as well as emotional engagement and unconscious dynamics. However, in comparison with technical competency, Spillane, Halverson and Diamond (2001) argue that non-technical competency such as El is often overlooked when assessing the impact of leadership and school change although it is viewed as a significant component in education. Beatty (2000) and Patti et al (2015) point out that it is important not to disregard El if the intended outcomes were school improvement and effectiveness through successful leadership.

To frame the above insights, it can be summarized that leadership, change and competency have a distinct relationship. Basically, change calls for leadership and leadership requires certain competencies if it is to be effective in driving change. Change can only be realized and sustained 
INTERNATIONAL JOURNAL OF ACADEMIC RESEARCH IN BUSINESS AND SOCIAL SCIENCES

Vol. 9, No. 6, June, 2019, E-ISSN: 2222-6990 @ 2019 HRMARS

continually if leaders are equip with technical and non-technical competencies so that they are able to engage both intellectually and emotionally in the process of change. Therefore, by conceptualizing leadership in a change context based on critical technical and non-technical competencies, leadership development not only can be more comprehensively understood, it can be fine-tuned for greater potential contribution to any organizational change.

\section{The Conceptual Framework of the Study}

The study was confined to one main variable i.e. competency in managing change (CIMC) of school principals in Malaysian secondary school. As school leadership influence is manifested through the competencies of the leaders during the change process, CIMC is seen as central to the leadership process in school change. As shown in Figure 1, the CIMC is broadly divided into two dimensions, the Technical Competency and the Non-technical Competency. Technical Competency refers to the specific competency needed by school leaders to lead and drive school change effectively based on the different phases of change. It consists of four sub-dimensions: Goal Framing, Capacity Building, Defusing Resistance and Conflicts, and Institutionalizing. Goal Framing is the first phase in the strategic planning of any school change to identify the purpose and direction of the change. The change goal should be well-formulated and clear so as to give the staff the feeling that the school is implementing an important task. To realize the change goal, three important steps have been outlined for this phase of change: i) developing an achievable goal for the school; ii) presenting the main reasons for change; and iii) having a clear roadmap of how to realize the change goal (Tai, Omar \& Ghouri, 2018).

Figure 1. The conceptual framework of the study

\begin{tabular}{|c|c|}
\hline \multicolumn{2}{|c|}{ Competency in Managing Change (CIMC) } \\
\hline Technical Competency & Non-technical Competency \\
\hline Goal Framing & $\begin{array}{c}\text { Emotional Perceiving \& } \\
\text { Expressing }\end{array}$ \\
\hline Capacity Building & Emotional Utilization \\
\hline $\begin{array}{l}\text { Defusing Resistance } \\
\text { \& Conflirts }\end{array}$ & Emotional Understanding \\
\hline Institutionalizing & Emotional Regulation \\
\hline
\end{tabular}


INTERNATIONAL JOURNAL OF ACADEMIC RESEARCH IN BUSINESS AND SOCIAL SCIENCES Vol. 9, No. 6, June, 2019, E-ISSN: 2222-6990 @ 2019 HRMARS

Capacity Building is the second phase of the school change process (Tai et al., 2018). Before the change starts, it is essential for school principals to examine the readiness of the teachers whether they posses sufficient competence to meet change requirements. Based on the results of the assessment, training programs need to put in place to establish teachers' capacity. Teachers' capacity building will enhance teachers' efficacy to carry out the new task efficiently. No teacher will embrace any school change if they are not ready to do so or not competent to conduct the new task (Tai et al., 2018). This phase of school change includes three functions: i) seeking ways to develop the competencies of the staff in teaching and learning; ii) providing the staff with training in coaching; and iii) Enabling the staff to perform the new task (Tai et al., 2018).

Defusing Resistance and Conflict is the third phase of the change (Tai et al., 2018). The heart of any school reform is the buy-in of the teachers to work through the change process because they are the change implementers closest to the students. However, as change is a stressor, people normally do not like change (Kotter, 1999; Hayes, 2010). Consequently, teachers may manifest a variety of actions to resist change. Additionally, it is very common that conflicts will exist among teachers in the change process; conflicts that will jeopardize change efforts as well as change outcomes. The associated significant competencies for school principals in handling Defusing Resistance and Conflict include i) anticipating the resistance behaviors that threaten the change initiatives; ii) making individuals who resist change feel ease and confident; and iii) managing change conflict effectively by seeking consensus from each party (Tai et al., 2018).

Institutionalizing is the last phase of the school change (Tai et al., 2018). After concerted efforts have been taken to make change happens, it is important to sustain the achievements of the change or make the change permanent by moving fitting it into organization's culture and practices or else the members of the organization probably will slip back into the old ways of working (Lewin, 1958; Kotter, 1999; Nilakant \& Ramanarayan, 2006; Hayes, 2010). As change is all too often shortlived, to ensure the process of continuous improvement and institutionalizing, school principals need to take three important steps in this phase of change: i) analyzing objectively the final change outcomes; ii) creating chances for the department for sharing best practices; and iii) ensuring staff members continually contribute to changes that were made (Tai et al., 2018).

The Non-technical Competency refers to those interpersonal and adaptive competencies in which the school leaders conduct themselves and interact with the working environment that makes human work more efficient. Importantly, it complements and supports those technical competencies making them more effective in leading change in schools. Specifically in this study, the Non-technical Competency refers to the El of school leaders in leading change whereby their cognitive competence are informed by emotions and their emotions are managed cognitively. It encompasses four subdimensions: Emotional Perceiving and Expressing, Emotional Utilization, Emotional Understanding and Emotional Regulation (Tai et al., 2018).

Emotional Perceiving and Expressing is defined as the ability of school principal to perceive, differentiate and express emotions in the self and others. The ability to perceive a person's emotions (type and intensity) accurately facilitates the understanding of that person's subsequent behaviors whereas expressing emotions accurately to others enable school principals to address emotional issues to the right person in the right time and place (Tai \& Omar, 2018b). Emotional Utilization is conceptualized as the ability of school principal to harness oneself and others' emotions in order to 
INTERNATIONAL JOURNAL OF ACADEMIC RESEARCH IN BUSINESS AND SOCIAL SCIENCES Vol. 9, No. 6, June, 2019, E-ISSN: 2222-6990 @ 2019 HRMARS

facilitate cognitive activities, for examples, thinking, judgement and problem solving, leading to effective performance. The capability to integrate the experience of emotion into positive cognitive activities is critical in handling of complex problems in the change process. This capability will help school principals to settle arguments, defuse resistance and change conflicts and turn change goals into reality (Tai \& Omar, 2018b).

Emotional Understanding is conceptualized as the school principal's ability to understand the relationships among different emotions, the causes and the consequences, the complex feelings and transitions among emotions in self and others. Building self-awareness about one's own emotions and feelings will enable individuals to understand other better; understanding the emotions of others will lead to the creation of the primacy of secure relationships among the staff that would be more likely to engage them to change (Tai et al., 2018). Emotional Regulation is viewed as the school principal's adaptive ability to reduce, prevent, modify or enhance an emotional response in oneself and others to achieve desired goals. It is essential for maintaining good relationships in the organization and provides a basis for enhancing job satisfaction (Sy, Tram \& O'Hara, 2006; Wong \& Law, 2002). It is essential for school principals to recognize that accurately regulating emotions is one of the effective ways that can lead to the achievement of the intended change goals.

\section{Methodology \\ Sample}

To gain a better perspective, the study involved all the 16 states/federal territories in Malaysia. For every state/federal territory, five secondary schools were selected randomly or a total of 80 schools $(16 \times 5)$ were involved in the study. In each school, fifteen teachers who have been teaching at least one year were chosen randomly as respondents. Simply put, a total number of 1,200 teachers ( $80 \mathrm{x}$ 15) were selected for the survey (Table 1).

Table 1.

Total number of teachers engaged in the survey

\begin{tabular}{lcccc}
\hline Respondents & $\begin{array}{c}\text { Number of } \\
\text { respondents } \\
\text { identified in } \\
\text { every school }\end{array}$ & $\begin{array}{c}\text { Total number } \\
\text { of respondents } \\
\text { identified for } \\
\text { the survey }\end{array}$ & $\begin{array}{c}\text { Total number of } \\
\text { returned } \\
\text { questionnaires } \\
\text { (response rate) }\end{array}$ & $\begin{array}{c}\text { Total number } \\
\text { of usable } \\
\text { data }\end{array}$ \\
\hline Teacher & 15 & 1,200 & $937(78.08 \%)$ & 901 \\
\hline
\end{tabular}

\section{Survey instrument}

CIMC was examined using Competency in Managing Change Scale (CIMCS) that was developed by Tai et al (2018) in the Malaysian education setting. It consists of two main dimensions and each dimension encompasses four sub-dimensions as shown in Figure 1. With only 28 items, it was psychometrically sound with normed chi-square=4.13, TL=.947, CFI=.952 and RMSEA=.059 Hair, Black, Babin \& Anderson, 2010). The CIMCS held composite reliability (CR) of .74, .75, .74, .75, .75, $.80, .83$ and .80 for the above eight sub-dimensions, respectively. Besides, the Averaged Extracted Value (AVE) all higher than 50\% (Fornell \& Larker, 1981), with a range of $59 \%$ to $75 \%$ that held 
INTERNATIONAL JOURNAL OF ACADEMIC RESEARCH IN BUSINESS AND SOCIAL SCIENCES

Vol. 9, No. 6, June, 2019, E-ISSN: 2222-6990 (C) 2019 HRMARS

convergent validity. The CIMCS also provided evidence for discriminant validity as the AVEs of the factors were higher than 0.50 and the CR index surpassed 0.70 (Hair, et al., 2010). The CIMCS is a sixpoint Likert scale. The data interpretation of this study is based on two main indicators, the frequency of the performance and the performance rating of satisfactory-dissatisfactory as shown in Table 2.

Table 2.

Raw scores of CIMC and its level and indicators

\begin{tabular}{llll}
\hline Raw Scores & Level of CIMC & \multicolumn{2}{c}{ Indicators } \\
\hline & & $\begin{array}{l}\text { Frequency of the } \\
\text { Performance }\end{array}$ & Performance \\
& & Rating \\
\hline $5.51-6.00$ & Very good & Almost all of the time & Very satisfactory \\
$5.01-5.50$ & Good & Satisfactory \\
$4.01-5.00$ & Quite good & Quite Often & Quite satisfactory \\
$3.01-4.00$ & Fair & Sometimes & Average \\
$2.01-3.00$ & Quite poor & Quite Rarely & Quite \\
$1.51-2.00$ & Poor & Rarely & Dissatisfactory \\
& & & Dissatisfactory \\
$1.00-1.50$ & Very poor & Almost Never & Very \\
& & & Dissatisfactory \\
\hline
\end{tabular}

\section{Data Analysis}

As shown in Table 1, of all the questionnaires sent out via post, 937 of 1,200 questionnaires were returned by teachers, representing a response rate of $78.08 \%$. However, only 901 questionnaires of the teachers were accepted for the final analysis, as some of the questionnaires were deemed incomplete or had at least $25 \%$ illegible responses. The above data collection adhere all ethical consideration. The study employed descriptive statistical analysis whereby data was analyzed based on mean scores and percentages. Table 3 shows the breakdown of demographic variables of the respondents. Besides, based on the .05 significance level, the $t$-test was also conducted to examine the difference between the variables. 
INTERNATIONAL JOURNAL OF ACADEMIC RESEARCH IN BUSINESS AND SOCIAL SCIENCES Vol. 9, No. 6, June, 2019, E-ISSN: 2222-6990 (C) 2019 HRMARS

Table 3.

Demographic characteristics of the respondents

\begin{tabular}{rrrr}
\hline & Category & Frequency & Per cent (\%) \\
\hline Gender & Male & 234 & 25.97 \\
& Female & 667 & 74.03 \\
& $21-30$ & 46 & 5.11 \\
Race Group & $31-40$ & 233 & 25.86 \\
& $41-50$ & 406 & 45.06 \\
& $51-60$ & 216 & 23.97 \\
& Malay & 724 & 80.36 \\
Highest Education Level & Chinese & 100 & 11.10 \\
& Indian & 31 & 3.44 \\
& Others & 46 & 5.10 \\
Years in Present Job & First Degree & 770 & 85.46 \\
& Master's Degree & 130 & 14.43 \\
& Ph.D & 1 & 0.11 \\
& $1-5$ & 115 & 12.76 \\
& $6-10$ & 145 & 16.09 \\
& $11-15$ & 135 & 14.98 \\
& $16-20$ & 195 & 21.64 \\
& $>20$ & 311 & 34.53 \\
\hline
\end{tabular}

\section{Findings}

As shown in Figure 2, the mean score of CIMC of school principals was 4.98. Based on the raw scores and the level of CIMC displayed in Table 2, the teachers rated their school principals as Quite Good in CIMC as the mean scores fell within 4.01 to 5.00. In terms of dimension, Figure 1 revealed that the level of Technical Competency and Non-technical Competency also achieved the level of Quite Good as the mean scores were 4.99 and 4.97, respectively. Although a difference of 0.02 was observed between these two mean scores but the difference was not significant, $t=.705, d f=1800, p>.05$ (Table 4). 
INTERNATIONAL JOURNAL OF ACADEMIC RESEARCH IN BUSINESS AND SOCIAL SCIENCES Vol. 9, No. 6, June, 2019, E-ISSN: 2222-6990 (C) 2019 HRMARS

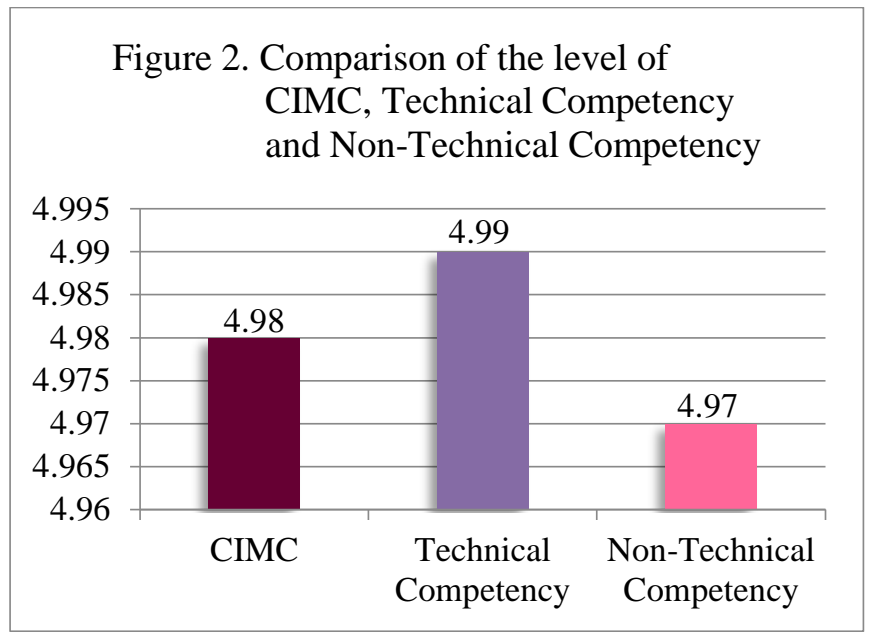

Table 4.

Independent samples test for technical and non-technical competency

\begin{tabular}{|c|c|c|c|c|c|c|c|c|c|c|}
\hline & & \multirow[b]{2}{*}{$F$} & \multirow[b]{2}{*}{ Sig. } & \multirow[b]{2}{*}{$t$} & \multirow[b]{2}{*}{$\mathrm{df}$} & \multirow[b]{2}{*}{$\begin{array}{l}\text { Sig. (2- } \\
\text { tailed) }\end{array}$} & \multirow{2}{*}{$\begin{array}{c}\text { Mean } \\
\text { Differe } \\
\text { nce }\end{array}$} & \multirow{2}{*}{$\begin{array}{c}\text { Std. } \\
\text { Error } \\
\text { Differen } \\
\text { ce }\end{array}$} & \multicolumn{2}{|c|}{$\begin{array}{c}95 \% \\
\text { Confidence } \\
\text { Interval of } \\
\text { the } \\
\text { Difference }\end{array}$} \\
\hline & & & & & & & & & $\begin{array}{l}\text { Low } \\
\text { er }\end{array}$ & $\begin{array}{c}\text { Uppe } \\
\text { r }\end{array}$ \\
\hline \multirow[t]{2}{*}{$\begin{array}{l}\text { Compe } \\
\text { - } \\
\text { tency }\end{array}$} & $\begin{array}{l}\text { Equal } \\
\text { variances } \\
\text { assumed }\end{array}$ & $\begin{array}{r}5.02 \\
2\end{array}$ & $\begin{array}{r}.02 \\
5\end{array}$ & .705 & 1800 & .481 & .023 & .032 & -.04 & .085 \\
\hline & $\begin{array}{l}\text { Equal } \\
\text { variances } \\
\text { not } \\
\text { assumed }\end{array}$ & & & .705 & $\begin{array}{r}1785.6 \\
89\end{array}$ & .481 & .023 & .032 & -.04 & .085 \\
\hline
\end{tabular}

In terms of sub-dimensions, as shown in Figure 3, school principals were rated as Good in Goal Framing $(M=5.21)$, Emotional Regulation $(M=5.12)$, Emotional Utilization $(M=5.09)$ and Institutionalizing $(M=5.04)$ as the mean scores fell within 5.01 t0 5.50. On the other hand, school principals were rated as Quite Good in Capacity Building $(\mathrm{M}=4.93)$, Emotional Perceiving and Expressing ( $M=4.86)$, Emotional Understanding $(M=4.80)$ as well as Defusing Resistance and Conflicts $(M=4.75)$ as the above mean scores fell within 4.01 to 5.00 . Comparatively, among all the subdimensions of CIMC, school principals obtained the highest mean score in Goal Framing $(M=5.21)$ and achieved the lowest mean score in Defusing Resistance and Conflicts ( $M=4.75$ ). 
INTERNATIONAL JOURNAL OF ACADEMIC RESEARCH IN BUSINESS AND SOCIAL SCIENCES Vol. 9, No. 6, June, 2019, E-ISSN: 2222-6990 @ 2019 HRMARS

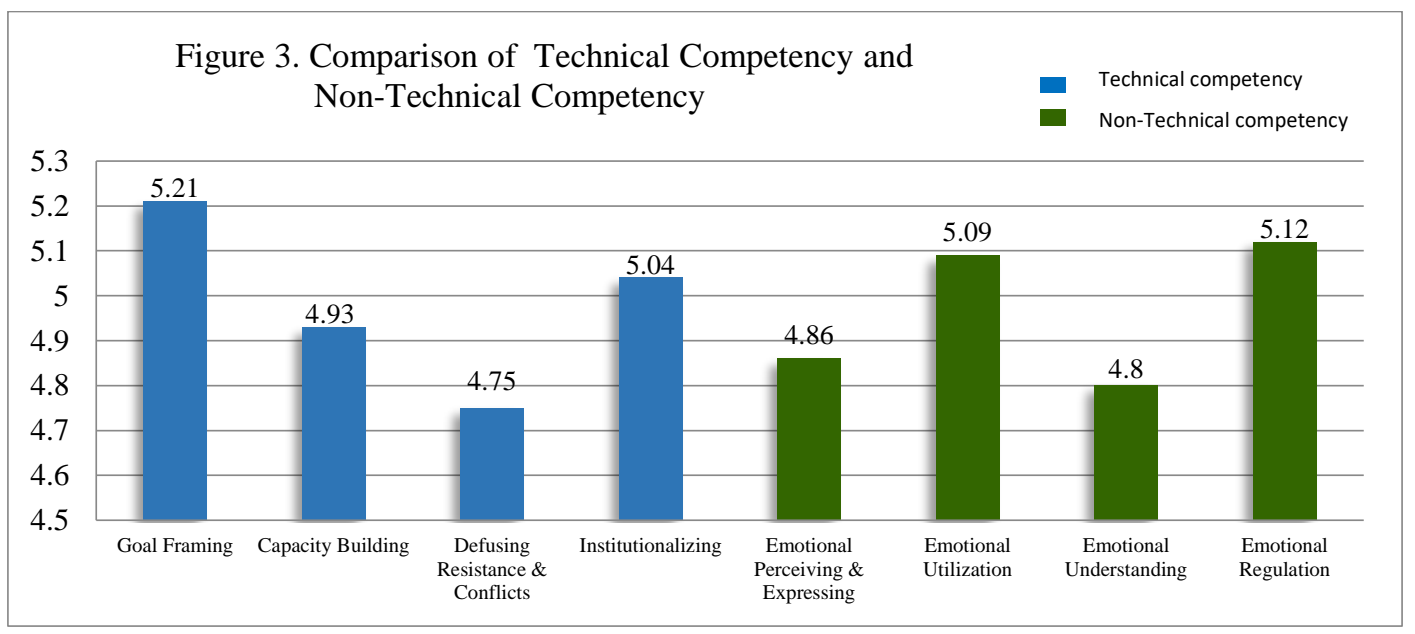

In summary, a) as a whole, the school principals were rated as Quite Good in CIMC; b) both Technical Competency and Non-technical Competency of school principals also at the level of Quite Good and there was no significant difference between these two competencies; c) in terms of subdimensions of CIMC, the school principals were rated as Good in Goal Framing, Institutionalizing, Emotional Utilization and Emotional Regulation but Quite Good in Capacity Building, Defusing Resistance and Conflicts, Emotional Perceiving and Expressing as well as Emotional Understanding; and d) among all the sub-dimensions of CIMC, the school principals obtained the highest mean score in Goal Framing and achieved the lowest mean score in Defusing Resistance and Conflicts.

\section{Discussion}

Based on the findings above, few significant insights have gleaned from the study. Firstly, as a whole, the school principals achieved the level of Quite Good in CIMC. Based on the raw scores and the level of CIMC suggested in the study, this revealed that the school principals only had demonstrated CIMC 'quite often' with 'quite satisfied' performance. This implied that the level of practising CIMC of the school principals in Malaysian secondary schools is yet to be enhanced. To best lead change in the schools, it is essential for the school principals to 'often' practise CIMC with 'satisfied' performance instead of 'quite often' in terms of frequency with 'quite satisfied' performance. As mentioned earlier, only school leaders equip with concerned change leadership competencies are able to drive and transform the schools effectively.

Contributory factors to the above phenomenon may include the preparation and development program for school leaders that affect the concerned leadership practice and behaviour (Mitgang, 2012; Tai \& Omar, 2018a). Indeed in the year 2009, Institut Aminuddin Baki (IAB) --- the national institute of educational management and leadership of the Ministry of Education Malaysia (MOE) had employed a training need analysis study among the school leaders in Malaysia. The results revealed that managing change is the most needed competency ( $M=3.85)$ among the eight critical competencies identified by the school principals in driving school effectiveness (Rosnarizah, Amin \& Razak, 2009). Since then, to ensure school leaders are able to manage school change effectively, change management has been introduced as an important component for school leaders' professional development courses in Malaysia. 
INTERNATIONAL JOURNAL OF ACADEMIC RESEARCH IN BUSINESS AND SOCIAL SCIENCES Vol. 9, No. 6, June, 2019, E-ISSN: 2222-6990 @ 2019 HRMARS

For example, change management has become one of the important modules for the National Professional Qualification for Educational Leaders (NPQEL) program, the mandatory preparatory training program for all new school principals in Malaysia (IAB, 2015; IAB, 2016; IAB, 2017). It is also an important tenet for the Program Residency and Immersion or PRIme --- another leadership development program for those soon-to-be appointed principals (IAB, 2015; IAB, 2016; IAB, 2017). Besides, change management is part of the important content for the School Transformation Program 2025 that had launched in 2015 by MOE with the aim for school improvement and effectiveness (Ministry of Education, 2017).

Although emphasis has been given to improve, the competency of managing change of school leaders in different professional development and CPD programs, whether it is effective depends on several important related factors. For instance, instead of a single approach, the effectiveness of the professional development and CPD programs can be realized through a balanced and comprehensive approach (Michaelidou \& Pashiardis 2009; Petridou, Nocolaidou \& Karagiorgi, 2017; Tai \& Omar, 2018a). Specifically, in maximizing learning impacts, different pathways of professional development with multi-phase designs and modularization of the program should be applied in achieving the purpose (Tai \& Omar, 2018c). According to Hoestra, Beijaard, Brekelmans and Korthagen (2009), Opfer and Pedder (2011), the content of professional development and CPD program should able to help school leaders to address affective, cognitive, behavioural and motivational aspects in schools as real change can only occur while all of the mentioned aspects are addressed effectively.

Other factor might due to the disconnection between theory and practice. High-quality professional development and CPD program need to ensure that there is a more applied and experiential form of learning that is job-embedded, where school leaders can connect theory, practice and student outcomes for continuous school improvement (Goldring, Preston \& Huff, 2010; Nicolaidou and Petridou 2011); instead of acquiring more knowledge, the program' emphasis is more about making sense of the current knowledge, hence developing reflective skills as a way of exploring and reforming practice (Dempster, Lovett \& Fluckiger, 2011; Huber 2008; Tai \& Omar, 2018c); the various program offer to school leaders should be customized as they vary in their needs at different school contexts and school developmental stages, as well as at different points in their careers (Tai \& Omar, 2018a). This is particularly true with professional development program that apply a one-sizefits-all approach (Joyce \& Calhoun, 2010).

Secondly, the finding showed that both Technical Competency and Non-technical Competency of school principals also at the level of Quite Good and there was no significant difference between these two competencies. This implied that there is room for improvement for school principals to enhance both Technical Competency and Non-technical Competency in near future if it is to be effective to drive school change effectively and ultimately to realize the change goals. Besides, the finding also revealed that equal emphasis had been given by IAB to both Technical Competency and Non-technical Competency during the professional development and CPD program and the school leaders also learnt and applied both the concerned competencies in the process of managing school change. In fact, as school is a complex organization school leadership needs to be embedded in a broader social relationship. School change can only be successfully implemented if school leaders involve themselves in rational and cognitive activities as well as emotional 
INTERNATIONAL JOURNAL OF ACADEMIC RESEARCH IN BUSINESS AND SOCIAL SCIENCES Vol. 9, No. 6, June, 2019, E-ISSN: 2222-6990 @ 2019 HRMARS

engagement that have direct demands on school leaders' cognition, affective, behavioural and motivation states (Opfer \& Pedder, 2011).

Thirdly, a close examination in terms of the sub-dimensions of CIMC revealed the school principals were rated as Good in Goal Framing, Institutionalizing, Emotional Utilization and Emotional Regulation. The school principals were rated as Good in Goal Framing implied that they 'often' practise Goal Framing with 'satisfied' performance i.e. they were always able to develop achievable change goals for the school; to present the reasons why they wanted to have change; and to have a clear direction of how to achieve the change goals effectively. The likelihood of school principals in engaging teachers to the change would be relatively high if they often practise Goal Framing as it is a vital initial step in implementing any school change (Tai \& Omar, 2018a).

The school principals were rated as Good in Institutionalizing implied that they 'often' practised and had given emphasis to the importance of sustaining the outcomes of the change with 'satisfied' performance. To this end, they were always able to analyse whether the change was implemented as what they had planned and whether the implemented change was having the intended impacts; opportunities were always being created for departments in sharing best practices and made sure that the new ways of working and the concerned achievements became the norms for the whole school; they always able to ensure that teachers continually contribute to the changes made, for instance, to develop a mechanism to align or refine the new state continually (Tai \& Omar, 2018a).

The school principals were rated as Good in Emotional Utilization implied that they had 'often' displayed Emotional Utilization with 'satisfied' performance. School principals were rated as Good in this component indicated that they were always able to use emotion in directing and focusing their attention on pressing concerns and situations; in adopting a better emotional state in choosing among alternatives and solving problems; to use emotion in facilitating cognitive processes; and to use shifts in emotions to promote flexibility. In short, school principals were always able to use Emotional Utilization to cope with disagreement, defuse resistance or conflicts in the change process (Tai \& Omar, 2018b).

The school principals were also rated as Good in Emotional Regulation. School principals were rated as Good in Emotional Regulation implied that they had 'often' displayed Emotional Regulation with 'satisfied' performance. They were always able to reflectively monitor and manage the positive as well as the negative emotions of self and others. Additionally, they were always knew how to respond effectively to an emotional experience in both self and others by employing effective alternative behaviors to produce the intended outcome in the change process. School change is inherently emotional and produces a range of feelings and emotions in individuals (Tai \& Omar, $2018 b)$. School principals need to use a variety of emotional regulation strategies and apply it to different situations as the enhancement of the principal-teacher relationship contributes to workplace outcomes and organizational productivity.

On the other hand, it was found that school principals were perceived as Quite Good in Capacity Building, Defusing Resistance and Conflicts, Emotional Perceiving and Expressing as well as Emotional Understanding. The school principals were rated as Quite Good in Capacity Building implied that they only had demonstrated the competency of Capacity Building 'quite often' with 'quite satisfied' performance. Capacity Building focuses on how school principals develop the 
INTERNATIONAL JOURNAL OF ACADEMIC RESEARCH IN BUSINESS AND SOCIAL SCIENCES Vol. 9, No. 6, June, 2019, E-ISSN: 2222-6990 @ 2019 HRMARS

capacity of the staff to face the challenges of the change, enhance their efficacy to work through the change process and ensuring their performance meet the required quality of the change (Tai \& Omar, 2018a). These included the school principals 'quite often' taking the initiatives to develop the competence of the staff in teaching and learning; providing the staff with training in coaching; and enable the staff to perform the new task effectively (Tai \& Omar, 2018a). As deficiency in staff's capacity will slow down the change, hence school principals need to enhance their competency in Capacity Building so as to enhance the school's readiness and capacity to succeed in the change.

The school principals were also rated as Quite Good in Defusing Resistance and Conflicts. This implied that they were 'quite often' practiced the above behaviors with 'quite satisfied' performance in managing school change. In other words, they were quite often able to anticipate the resistance behaviours of the staff that threaten the change initiatives; to make individuals who refuse to accept the change feel ease and confident; and to defuse change conflicts by obtaining consensus from each party (Tai \& Omar, 2018a) with quite good performance. Indeed, resistance to change is the main reason why organizational change efforts difficult to be obtained (Deloitte \& Touche, 1996). As the school principals are still at the level of Quite Good for this competency therefore they need to improve it urgently as it is crucial to turn change goal into reality.

Meanwhile, the school principals were also rated as Quite Good in Emotional Perceiving and Expressing. School principals were rated as Quite Good in this component, indicated that they were 'quite often' able to identify and differentiate emotions accurately in their staff members through appearance, expression or behavior; to accurately express his or her feelings accurately and according to the needs of the staff when weathering the change with 'quite satisfied' performance. Both the above abilities of school principals enable them to facilitate the understanding of their staff and help them to address emotional issues to the staff accurately in the right time and place. As such, it is essential for school principals to enhance their ability in Emotional Perceiving and Expressing so that the school leaders able to avoid stereotyping that may lead to performance deficits in the school change when enacting change initiatives.

Besides, the school principals were also rated as Quite Good in Emotional Understanding. In other words, they had 'quite often' displayed Emotional Understanding with 'quite 'satisfied performance. This indicated that they were quite often able to understand how emotions evolve and change over time; the determinants of emotions; the complex feelings; the relationships among various emotions; and transitions among emotions (Tai \& Omar, 2018b). Working in today's challenging people-intensive educational context, understanding the emotions of the staff has the potential to facilitate an effective school leadership in multiple ways that enable school leaders in the nurture and building up of a conducive emotional climate. As the school principal still at the level of Quite Good for this component, it is essential for them to enhance this competency adequately as it is crucial to improve organizational productivity in the face of change.

Fourthly, the finding also demonstrated that among all the sub-dimensions of CIMC, the school principals obtained the highest mean score in Goal Framing. This indicated that the ability and initiatives of school principals to develop attainable change goals, presenting the moral purpose of the change and having a clear roadmap of how to realize the change goals were the most sufficient in comparison with other sub-dimensions. As Malaysia is implementing a centralized rather than a decentralized school system, conformity is essential within the hierarchy of authority. As change 
agents as well as instructional leaders, school principals are at the center of the school change. They are responsible to initiate, implement, monitor and sustain any change kicks off by the MOE. In relation to this, they are expected to initiate the behaviors of Goal Framing successfully based on the vision set up by the MOE. They were always able to formulate the change goals based on the needs and the instructions from the MOE; communicate and articulate the change goals to the staff and various stakeholders; and identify alternatives to achieve the change goals. Therefore, this should not come as a surprise why the school principals obtained the highest mean score in Goal Framing.

Fifthly, the finding also revealed that among all the sub-dimensions of CIMC, the school principals obtained the lowest mean score in Defusing Resistance and Conflicts. Simply put, in comparison with other sub-dimensions, school principals demonstrated the least competence in this component. Indeed, to change the attitude of the staff from resisting to embracing the change is not an easy task; to gain the change recipients' minds and hearts is the most challenging endeavours in leading change in any organization. Fullan (1993) highlights that focusing on people is the most effective way to drive educational change; the organization will change when people within the organization adopt the change. If school principal fail to do so, negative emotions such as frustration, anger, resent, stresses, fear or anxiety will be generated in the organization, causing disconnect and unsuccessful implementation (Tai \& Omar, 2018a). Therefore it is important to note that human factor is relatively a crucial factor that affects the change as any effective and sustainable change resides within the human system (Juechter, Caroline \& Alford, 1998).

\section{Limitations and future direction of the study}

A few limitations should be noted in the current study. To gain a different perspective of the phenomenon and to enhance the capacity to interpret the findings, future research should be designed to collect the data from school principals, the change agent as well as another third party, the senior assistants. The current study is also limited by the approach of the research. As school change is a complex subject and is context-specific, instead of just conducting a survey study, it would be meaningful if future studies could allow for a longitudinal design to collect sufficient data within a longer time span. Lastly, the assumption made in the present study regarding the relationships between the contributory factors and the level of Quite Good in CIMC achieved by the school principals have to be examined further by using the concerned instruments to identify the extent of the impact of the factors upon CIMC. This certainly will advance our understanding of the phenomena greatly.

\section{Conclusion}

Change is an important facet of leadership. To drive school change effectively, it is essential for school leaders to equip with subsequent change leadership competencies, both technical and non-technical. As school leadership is not task driven per se but emotionally compelling, school change can only be realized and sustained continually if school principals are able to engage both intellectually and emotionally in the process of change. In summary, school principals in Malaysia achieved the level of Quite Good in CIMC implied that there is room for improvement to enhance their CIMC to meet the requirements as change agents to initiate school reforms effectively as outlined in the Malaysia Education Blueprint 2013-2025. Although MOE had given equal attention to develop both technical 
and non-technical competencies of school principals in managing change, concerted efforts need to be taken by MOE to identify the root cause why the school principals were still at the level of Quite Good in CIMC.

In summary, this study provides a preliminary insight into emerging patterns and typology of CIMC in Malaysian secondary schools. Specifically, it provides the MOE with useful feedback in designing change management training program based on the distinct needs of school leaders; resources can be targeted more accurately so that school leaders can be equipped with essential CIMC and able to bring their schools to a transformational edge. The study also offers local practitioners and relevant parties yet another dimension of enhancing and enlarging school principals' capacity for change. Additionally, the study contributes to the field of educational change management particularly in advancing a more comprehensive analysis in exploring CIMC towards continuous school improvement and may help move the literature of school change management to a more coherent theoretical perspective.

Funding: This research was funded by GPU Khas Pendidikan Research Grant Scheme (Grant number: 2017-0250-107-01), Sultan Idris Education University, Malaysia.

Acknowledgement: The authors are grateful to Sultan Idris Education University, Malaysia for providing the GPU Khas Pendidikan Research Grant Scheme that has enabled the authors to conduct the studies.

\section{References}

Balogun, J., \& Hope-Hailey, V. (2004). Exploring strategic change ( $2^{\text {nd }}$ ed.). London: Prentice Hall.

Beatty, B. (2000). The emotions of educational leadership: Breaking the silence. International Journal of Leadership in Education, 3(4), 331-357. doi:10.1080/136031200750035969

Bennis, W., \& Nanus, B. (1985). Leadership: The strategies for taking charge. New York, NY: Harper \& Row.

Cotton, K. (2003). Principals and student achievement: What research says? Alexandria, VA: Association for Supervision and Curriculum Development.

Deloitte \& Touche. (1996). Executive survey of manufacturers. Retrieved from http://www. dtcg.co/research

Dempster, N., Lovett, S., \& Fluckiger, B. (2011). Strategies to developing school leadership: A select literature review. Melbourne: Australia Institute for Teaching and School Leadership.

Elliott, C. (1992). Leadership and change in schools. Issues in Educational Research, 2(1), 45-55.

Fornell, C., \& Larcker, D. (1981). Structural Equation Models with unobservable variables and measurement error: Algebra and statistics. Journal of Marketing Research, 18(August), 382-388. 
INTERNATIONAL JOURNAL OF ACADEMIC RESEARCH IN BUSINESS AND SOCIAL SCIENCES

Vol. 9, No. 6, June, 2019, E-ISSN: 2222-6990 @ 2019 HRMARS

Fullan, M. (1993). Change forces probing the depths of education reform. London: The Falmer Press.

Fullan, M. (2007). The new meaning of educational change ( $4^{\text {th }}$ ed.). New York, NY: Teachers College Press.

Fullan, M. (2010). Leading in a culture of change. San Francisco, CA: Jossey-Bass

Goldring, E. B., Preston, C., \& Huff, J. (2010). Conceptualizing and evaluating professional development for school leaders. Paper prepared for the Asian Leadership Roundtable, Institute of Education, 11-12 January, Hong Kong.

Hair, J. F. Jr., Black, W. C., Babin, B. J., \& Anderson, R. E. (2010). Multivariate data analysis ( $7^{\text {th }}$ ed.). United States: Pearson.

Harris, A. (2004). Editorial - School leadership and school improvement: A simple and a complex relationship. School Leadership and Management, 24(1), 3-5.

Harris, A., Jones, M., \& Huffman, , J. B. (2018). Teachers leading educational reform: The power of professional learning communities. London, UK: Routledge.

Hayes, J. (2010). The theory and practice of change management ( $3^{\text {rd }}$ ed.). New York, NY: Palgrave Macmillan.

Hoekstra, A., Brekelmans, M., Beijaard, D., \& Korthagen, F. A. J. (2009). Experienced teachers' informal learning: Learning activities and changes in behaviour and cognition. Teaching and Teacher Education, 25, 363-373.

Huber, S. G. (2008). Leadership development and school development: Enhancing the leadership capacity in schools. In International Handbook on the Preparation and Development of School Leaders, edited by J. Lumby, G. Crow and P. Pashiardis, 163-175. New York: Routledge.

Hyland, P. K. (2007). Resistance to organizational change: The impact of followers' disposition toward change and supervisors' leadership style (Unpublished doctoral dissertation). Columbia University, Columbia.

Institut Aminuddin Baki (IAB). (2015).Training program 2015. Genting Highlands: Institut Aminuddin Baki.

Institut Aminuddin Baki (IAB). (2016). Training program 2016. Genting Highlands: Institut Aminuddin Baki.

Institut Aminuddin Baki (IAB). (2017). Training program 2017. Genting Highlands: Institut Aminuddin Baki.

Intagliata, J., Ulrich, D., \& Smallwood, N. (2000). Levering leadership competencies to produce leadership brand: Creating distinctiveness by focusing on strategy and results, Human Resource Planning, 23(3), 101-125.

Issah, M. (2018). Change Leadership: The Role of Emotional Intelligence. SAGE Open, July-September, 1-6. doi: 10.1177/2158244018800910

Joyce, B., \& Calhoun, E. (2010). Models of professional development: A celebration of educators. California: Thousand Oaks.

Juechter, W.M., Caroline, F., Alford, R.J. (1998). Five conditions for high performance cultures. Training and Development, 52(5), 63-76.

Kerfoot, K. (1999). On leadership. Nursing Economics, 17(1), 34-42. 
INTERNATIONAL JOURNAL OF ACADEMIC RESEARCH IN BUSINESS AND SOCIAL SCIENCES

Vol. 9, No. 6, June, 2019, E-ISSN: 2222-6990 @ 2019 HRMARS

Kotter, J. P. (1990). A force for change: How leadership differs from management. New York, NY: The Free Press.

Kotter, J.P. (1999). Leading change. Boston: Harvard Business School Press.

Leithwood, K.A., Seashore, L.K., Anderson, S., \& Wahlstrom, K. (2004). How leadership influences student learning: Learning from research project. US: University of Minnesota.

Lewin, K. (1958). Group decisions and social change. In G.E. Swanson, T.M. Newcomb \& E.L. Hartley (Eds.), Readings in Social Psychology (pp. 62-73). New York, NY: Holt, Rhinehart \& Winston.

Marzano, R. J., Waters, T., \& McNulty, B. A. (2005). School leadership that works: From Research to results. Alexandria, VA: Association for Supervision and Curriculum Development.

Michaelidou, A., \& Pashiardis, P. (2009). Professional development of school leaders in Cyprus: is it working? Professional Development in Education, 35(3), 399416.

Ministry of Education Malaysia. (2016). Annual report of Malaysia Education Blueprint 2013-2025. Putrajaya: Ministry of Education Malaysia.

Ministry of Education Malaysia. (2017). Report of School Transformation Programme. Putrajaya: Ministry of Education Malaysia.

Mitgang, L. (2012). The making of the principal: Five lessons in leadership training. New York, NY:The Wallace Foundation.

Mohamed, Z., Valcke, M., \& De Wever, B. (2017). Are they ready to teach? Student teachers' readiness for the job with reference to teacher competence frameworks. Journal of Education for Teaching, 43(2), 151-170

Nicolaidou, M., \& Petridou, A. (2011). Echoing school leaders' voices in Cyprus: a study of novice school leaders' perceptions regarding leadership professional development. Professional Development in Education, 37(5), $721-740$.

Nilakant, V., \& Ramanarayan, S. (2006). Change management: Altering mindset in a global context. New Delhi: Response Books.

Northouse, P. G. (2015). Leadership: Theory and Practice, 7th eds. SAGE Publication: Los Angeles.

Olivier, D. F., \& Huffman, J. B. (2016). Professional learning community process in the United States: Conceptualization of the process and district support for schools. Asia Pacific Journal of Education, 36(2), 301-317. Ddoi: org/10.1080/02188791.2016.1148856

Omar, A. K., \& Tai, M.K. (2018). The development of principal change leadership emotional intelligence model. International Journal of Managment in Education, 12(3), 276313. doi: 10.1504/IJMIE.2018.092871

Opfer, V.D., \& Pedder, D. (2011). Conceptualizing teacher professional learning. Review of Educational Research, 81(3), 376-407.

Oplatka, I. (2003). School change and self renewal: Some reflections from life stories of women principals. Journal of Education Change, 4(1), 25-43.

Pamer, J. J., \& De Waal, E. (2011). School change and emotional intelligence. 
INTERNATIONAL JOURNAL OF ACADEMIC RESEARCH IN BUSINESS AND SOCIAL SCIENCES

Vol. 9, No. 6, June, 2019, E-ISSN: 2222-6990 @ 2019 HRMARS

Journal of Social Science, 26(3), 171-181.

Patti, J., Senge, P., Madrazo, C., \& Stern, M. (2015). Growing school leaders who can grow learning cultures. In J.A. Durlak, C.E. Domitrovich, R.P. Weissberg \& T.P. Gullotta (Eds.), Handbook of social and emotional learning: Research and Practice. New York, NY: Guilford Publications.

Petridou, A., Nocolaidou, M., \& Karagiorgi, Y. (2017). Exploring the impact of $\quad$ p r o f e s s i o $\mathrm{n}$ a I development and professional practice on school leaders' selfefficacy: A quasi-experimental study. School Effectiveness and School Improvement, 28(1), 5673.

Rosnarizah, A.H., Amin, S., \& Abdul Razak, M. (2009). Innovation in educational management and leadership: High impact competency for Malaysian school leaders. Retrieved from www.seameo.org/vl/library/dlwelcome/projects/ jasper/.../FullPaper.pdf

Rothwell, W.J., Hohne, C.K., \& King, S.T. (2007). Human performance improvement: Building practitioner competence ( $2^{\text {nd }}$ ed.). USA: Butterworth-Heinemann.

Spillane, J. P., Halverson, R., \& Diamond, J.B. (2001). Investigating School Leadership Practice: A Distributed Perspective. Educational Researcher, 30(3), 23-28.

Sy, T.,Tram, S., \& O'Hara A. L. (2006). Relation of employee and manager emotional intelligence to job satisfaction and performance. Journal of Vocational Behaviour, 68, 461-473.

Tai, M. K., \& Omar, A. K. (2013). Principals change leadership competencies: A study in Malaysian high performing secondary school. Journal of Education and Practice, 4 (27), 101-116.

Tai, M. K., \& Omar, A. K. (2018a). A comparative analysis of principal change leadership competencies in Malaysian high- and mediocre-performing secondary schools. Asia Pacific Journal of Education. Advance online publication. doi:10.1080/02188791.2018.1476319

Tai, M. K., \& Omar, A. K. (2018b). Emotional intelligence of school principals in managing change: A comparison among high, mediocre and low-performing secondary schools in Malaysia. International Studies in Educational Administration, 46(3), 67-88.

Tai, M. K., \& Omar, A. K. (2018c). Headteacher change leadership competency: A study in Malaysian primary schools. Professional Development in Education.

Advance online publication. doi: 10.1080/19415257.2018.1561494

Tai, M.K., Omar, A.K., \& Ghouri, A.M. (2018). Developing a preliminary model onprofessional learning community in Malaysian secondary school Unpublished research report which was funded by Fundamental Research Grant Scheme [Code: 2017-0196-107-01], Ministry of Higher Education Malaysia). Sultan Idris Education University, Perak Darul Ridzuan, Malaysia.

Wong, C. S., \& Law, S. K. (2002). The effects of leader and follower emotional intelligence on performance and attitude: An exploratory study. Leadership Quarterly, 13, 243-274.

Yukl, G.A. (2002). Leadership in organization ( $5^{\text {th }}$ ed.). Upper Saddle River, NJ: 
INTERNATIONAL JOURNAL OF ACADEMIC RESEARCH IN BUSINESS AND SOCIAL SCIENCES Vol. 9, No. 6, June, 2019, E-ISSN: 2222-6990 @ 2019 HRMARS

Prentice-Hall. 